\title{
ACUTE INFECTIOUS LYMPHOCYTOSIS
}

\author{
By A. Dolphin, M.D., M.R.C.P., B.Sc. and R. D. PophaM, M.B., B.S. \\ Mile End Hospital, London
}

Only three cases of infectious lymphocytosis have been described as such in the English literature. Elsewhere about 70 cases have been described, almost entirely in the American literature. As the disease may be more common in England than the recorded cases would seem to indicate, it was thought worthwhile to report a case, review the literature and discuss the differential diagnosis with particular reference to the points of similarity to, and difference from, infectious mononucleosis.

\section{Case Report}

A girl of 19 months was admitted to hospital on November 13, 1948, with a history of 5 weeks' diarrhoea and occasional vomiting. Two weeks before admission these became more severe and a cough developed.

There were no past illnesses, no inoculations and no history of contact with tuberculosis.

Examination. The temperature was $100.4^{\circ} \mathrm{F}$., pulse rate 136 and respiration rate 28 per minute. There was some gingivitis and tonsillitis. Over both lungs there were scattered rhonchi. The heart, abdomen and nervous systems were normal. The stools were loose, offensive and yellow but contained no blood.

Investigations. Stools ; no pathogens found in three specimens. A smear from the gums showed Monilia albicans. Wassermann, Paul-Bunnell and Kahn reactions were all negative. Serum; no agglutination against $\mathrm{Br}$. abortus or $\mathrm{Br}$. melitensis. Mantoux $1 / 1,000$ was negative and chest $\mathrm{X}$-ray was normal. Total leucocyte count : 95,000 per c.cm.

Differential count :

Neutrophil polymorphs. . I4 per cent. (I 3,300 )

Lymphocytes . . . 84 per cent. $(79,800)$

Monocytes $\quad . \quad \ldots \quad 2$ per cent. $(1,900)$

Platelets, normal

The lymphocytes were the small, so-called ' mature' forms.

Progress. November 16. Total leucocytes, 128,000 per c.cm.

Differential count :

N. polymorphs. . .. 9 per cent. $($ I I, 520$)$

Eosinophils .. .. I per cent. $($ I, 280)

Lymphocytes . . . .83 per cent. (106,240)

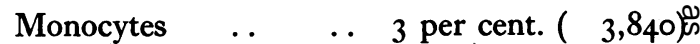

Metamyelocytes $\quad \ldots \quad 2$ per cent. $(2,560) 5$ Lymphoblasts ... .. 2 per cent. $(2,560)^{\circ}$

November 19. Paul-Bunnell test again negative $\vec{\rho}_{\mathrm{S}}$

November 25. Total leucocytes, 14,000 pefó c.cm.

Differential count ${ }^{\prime}$ :

N. polymorphs . .

. $\quad \ldots \quad 2$ per cent. $(280) B$

Lymphocytes $\quad \ldots \quad \quad \ldots \quad 4^{8}$ per cent. $(6,720){ }_{j}$

Monocytes $\quad$. $\quad$. 3 per cent. $(420)$ U

$\left.\begin{array}{ll}\text { Metamyelocytes .. } & \ldots \\ \text { Myelocytes } & .\end{array}\right\} 9$ per cent. $(1,260)^{\circ}$

November 26. The temperature, which pre-O viously was not above $100^{\circ} \mathrm{F}$., rose to $103^{\circ} \mathrm{F} \stackrel{\circ}{0}$ Since there was also some neck stiffness a lumbato puncture was performed. The C.S.F. pressure was normal and the fluid contained $20 \mathrm{mg}$. protein per $100 \mathrm{ml}$., no excess of globulin and normal cytologically.

November 29. Total leucocytes, 9,900 per c.cm.

Differential count :

N. polymorphs .. . . 47 per cent. $(4,653)$

Lymphocytes . . . . 50 per cent. $(4,950 \bar{D}$

Monocytes .. .. 3 per cent. ( 297 )

Paul-Bunnell test again negative.

The patient was now well, apart from occasiona? diarrhoea which persisted for another week.

Comment. Unusual features about the present case were the high total leucocyte count, which reached a level of 128,000 cells per c.cm., and the presence in the peripheral blood on one occasion of 2 per cent. lymphoblasts. We have been unable to find a higher total leucocyte count in this disease in the literature.

\section{Review of Previously Reported Cases}

Infectious lymphocytosis, which is characterized by a great increase in the number of small, sof called ' mature' lymphocytes in the peripheraf blood, was first claimed to be a distinct clinicat entity by Smith (I94I). He described acute and chronic forms of disease. In the acute form tho lymphocytosis is of short duration and there are no characteristic symptoms and few physicat signs. The chronic form is the more commori 
variety ; with it there is usually a mild pyrexia which may continue for weeks or months and is most frequently preceded by signs or symptoms of upper respiratory tract infection; other features may be abdominal pain, sometimes severe and accompanied by muscle rigidity, anorexia and fatigue.

Rayersbach and Lenert (I94I) described the occurrence of 16 cases in children of 'infectious mononucleosis without clinical signs or symptoms.' The children were convalescent after rheumatic fever and the abnormal blood picture was discovered accidentally when routine blood counts were done. Smith (1944) regarded the cases of Rayersbach and Lenert as cases of infectious lymphocytosis.

The first cases in the English literature were described by Kilham and Steigman (1942). Under the title of 'infectious mononucleosis' they described three cases of persistent lymphocytosis in which the cells affected were the small lymphocytes. There was enlargement of the cervical glands, the Paul-Bunnell reaction was negative and the authors believed the patients to have ' infectious lymphocytosis' as described by Smith (I94I).

Duncan's (1943) patient had frequent projectile vomiting but the chief symptom was abdominal pain and there was board-like rigidity of the abdominal muscles. The maximum leucocyte count was I I0,000 cells per c.mm., of which 92 per cent. were lymphocytes. The platelet count was normal apart from a fall to 90,000 on the 9th day.

Smith (1944) described the illness in four children, three being members of the same family; three of the patients were girls. When admitted to hospital the first had a temperature of $103^{\circ} \mathrm{F}$, was acutely ill and had had vomiting and abdominal pain for 12 hours previously. The tonsils were acutely inflamed and there was slight resistance and tenderness in the right iliac region. There was no enlargement of lymph glands or spleen. The leucocyte count was 45,000 per c.mm. with 72 per cent. lymphocytes. Within 24 hours the temperature fell and the abdominal pain subsided. The second patient developed a transient slight enlargement of the spleen. Sternal marrow count in one case showed 152,000 nucleated cells per c.mm. with 43 per cent. lymphocytes. Lymph gland biopsy showed extensive proliferation of the reticulo-endethelial cells; the lymph follicles were inconspicuous and showed no germinal centres.

Finucane and Phillips (1944) found 21 cases in the children's ward of a tuberculosis sanatorium. The leucocyte count ranged from 22,000 to 120,000 per c.mm. and the lymphocytosis from 62 per cent. to 97 per cent. The average duration of the leucocytosis was $4 \frac{1}{2}$ weeks.

Birge and Hill's (1945) patient was a girl of five years who developed coryza and right otitis. media. Five days later the leucocytes were 44,000 per c.mm. with 90 per cent. lymphocytesSlight fever continued for four weeks. Seven weeks after the onset of the illness diarrhoea occurredt. and the leucocyte count was 34,000 per c.mm with 72 per cent. lymphocytes; the blood counf did not return to nermal for a further five weeks. Duncan (1945) described the disease in two maleș aged 19 and 20 years.

Beloff and Gang (1945) described the occurrence्ల in a camp, within a short period of time, of casess of poliomyelitis and a case of infectious lympho $\frac{0}{3}$ cytosis. A small epidemic of non-specific diarrhoea first developed; then two cases of mumps occurred? A few days later the first case described by them a boy of four years, developed bulbar polio myelitis. A week later, their second patient, w్ girl of six years, developed infectious lympho-o cytosis. Her illness began with a mild upper. respiratory tract infection but the main symptomo was bloody stools ; she vomited once, had some? neck rigidity and slight right facial weakness. The leucocytes were 45,000 per c.mm. with 90 per cent. normal mature lymphocytes; the C.S. contained 50 cells per c.mm., 'mostly moni nuclears.' 'The Paul-Bunnel test was negatia. The third patient was a boy of 12 years who had a pyrexia of $102^{\circ} \mathrm{F}$., headache, tenderness in the parotid region and a positive Kernig's sign. Theo C.S.F. pressure was normal but the fluid containedô I4I cells per c.mm., of which Io per cent. were lymphocytes. Two days later the blood leucocyteso were 5,500 per c.mm., of which 57 per cent. were lymphocytes and 6 per cent. eosinophils. The final diagnosis was acute non-paralytic poliomyelitis or possibly mumps encephalitis. Another? patient seen by them developed what appeared. to be an acute infectious lymphocytosis, but six 3 days later multiple paralyses of the arms and legsi occurred.

MacInnis's (1946) patient was a girl of seven years who had a slight cough for some weeks and? then an epistaxis. The maximum leucocyte count was 30,000 with 85 per cent. small lymphocytes. Lorenz, Hardy and Alt (1946) described two cases $N$ of the disease; both patients were male. The maximum leucocyte changes were 66,000 per c.mm., of which 88 per cent. were lymphocytes. $\omega$ There was a mild respiratory infection, no en larged glands or spleen except in one patient inco whom the spleen became enlarged two months after the onset of the illness. In each case the ${ }^{-}$ Paul-Bunnell test was positive at a titre of $r / 80, \frac{0}{0}$ but the authors did not consider this of significance $\frac{\mathrm{C}}{\mathrm{O}}$ 
because ' it may be found in a variety of infections in children.'

Sita-Lumsden's (1947) patient was a boy of seven years who had diarrhoea for five weeks, abdominal pain and nocturnal sweating. When first seen the only abnormality was moderate enlargement of the left cervical glands. After two weeks the tonsils were slightly enlarged, the glands on the left side of the neck slightly enlarged, discrete and rubbery and the leucocytes 36,000 per c.mm., of which 75 per cent. were small lymphocytes. After a further two weeks the leucocytes rose to 52,000 , of which 76.5 per cent. were small lymphocytes. The Wassermann, Mantoux and Paul-Bunnell tests were negative. Sita-Lumsden noted that ' as in the cases reported by Finucane and Phillips a mild eosinophilia appeared as the total count fell.'

Sex incidence. Of the recorded cases where sex is stated there were 36 females to 20 males. In 12 cases the sex is not stated.

Incubation period. According to Smith (1944) and Beloff and Gang (1945) this is probably from 12 to 21 days.

\section{Diagnosis}

Of a disease which is so uncommon and not proven to be a distinct clinical entity it is difficult to discuss the differential diagnosis but conditions which require consideration are infectious mononucleosis, acute leukaemia, diseases associated with high lymphocytosis and, in some cases, the surgical acute abdomen.

Tidy (1950) stated that we are not yet familiar with all the clinical features of glandular fever and it would seem that differentiation between it and infectious lymphocytosis cannot be made clinically. In cases of infectious lymphocytosis many of the features of infectious mononucleosis have occurred such as tonsillitis, enlarged lymph glands, splenomegaly, meningism and abnormal neurological signs. In the cases in which leucocyte changes showed the greatest difference from those usually found in infectious mononucleosis, i.e. total count above 40,000 per c.cm. and lymphocytes at least 70 per cent., the most prominent clinical features have been symptoms of respiratory tract infection or abdominal features such as acute pain, sometimes associated with board-like rigidity, diarrhoea, which has sometimes continued for weeks, and blood in the stools. Those who believe that infectious lymphocytosis is a distinct disease base their opinion on the blood cell changes and the absence of a positive Paul-Bunnell reaction. The blood change claimed as characteristic is a great increase in the number of small 'mature' lymphocytes in the peripheral blood. Tidy stated that the leucocyte count in infectious
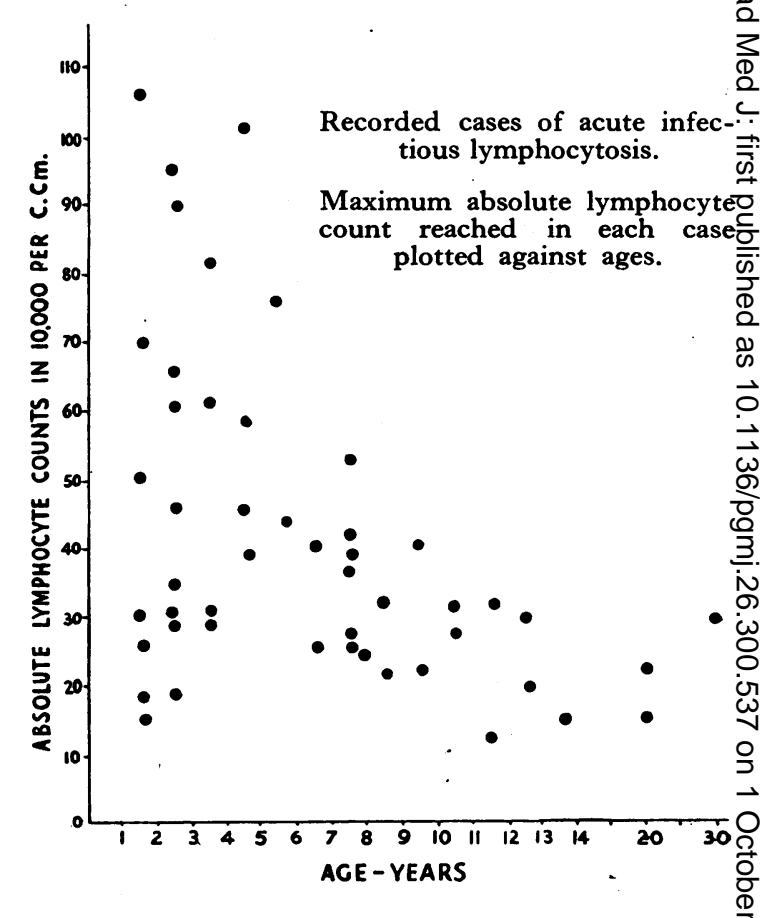

mononucleosis is rarely greater than 30,000 per. c.cm. and that a mononuclear percentage aboge 80 is rare and above 90 per cent. very rare. In the cases hitherto described as infectious lymphocytosis the total count has usually been above 45,000 per c.cm. and the lymphocyte figure commonly above 80 per cent. In the hitherto recorded cases the maximum total count was응 120,000 per c.cm. and 97 per cent. lymphocytes; in the present case the highest total count was 128,000 per c.cm., of which 84 per cent. were small lymphocytes. In some cases the maximum 3 leucocyte changes were found as the acute symp-:toms subsided; in other cases they occurred 3 during the acute stage. In case age might possibly be related to the blood picture in infectious lymphocytosis a graph was made plotting absolute ${ }_{\circ}$ lymphocyte counts against the ages of the patients (see fig.). An attempt to produce for comparison a graph for infectious mononucleosis was unsuccessful because of insufficient data concerning $N$ the type of lymphocyte involved.

Tidy states that there is no specific " infectious mononucleosis cell' and that it would be unsafe ${ }_{\sigma}^{\omega}$ to diagnose or, exclude glandular fever on the presence or absence of such cells because as the? attack subsided the surviving cell is the lymphocyte, large or small. He also states that a positive Paul-Bunnell test is proof of glandular fever but that a negative reaction does not exclude it, and市 
that a high titre and a rapid fall to negative may occur during a few days.

Epistaxis, which occurred in one reported case, and bloody stools may, in association with the hyperleucocytosis, lead to confusion with acute lymphatic leukaemia but in this disease the patient is more likely to be seriously ill and to have enlarged lymph glands and splenomegaly. The distinguishing peripheral blood changes are the presence of severe anaemia, thrombocytopoenia and lymphoblasts in acute leukaemia, features not found in acute infectious lymphocytosis although 2 per cent. of lymphoblasts were found on one occasion in the present case.

Extremely high leucocyte counts sometimes occur in pertussis but usually only in the severe cases and not in mild atypical attacks. Pearson and Newns (1937) described the occurrence of hyperleucocytosis in a boy, aged five years, who developed pertussis. A cough developed shortly after tonsillectomy and 16 days after operation he was admitted to hospital with tachypnoea, râles over the right lung, pleural rub in the right axilla, and spleen tip just palpable on deep inspiration. Chest X-ray showed pneumonia of the right lower lobe. Four days later the total leucocyte count was 145,000 per c.cm., of which 53 per cent. were 'mature' lymphocytes. An absolute lymphocytosis persisted for over four months. Pertussis occurred in the ward 37 days after their patient was admitted and their patient whooped a week later. It seems possible that this patient had acute infectious lymphocytosis when admitted̋ to hospital and afterwards developed pertussis as a result of contact with a source of infection in the ward.

In those cases of acute infectious lymphocytosis in which abdominal symptoms and signs were prominent features (Duncan 1943, and Smith등 1944), a blood examination may be the onlyen method of excluding conditions requiring surgicap treatment.

\section{Summary}

A case is described in which there occurred the blood changes claimed by Smith (194I) to bew characteristic of acute infectious lymphocytosis.

The maximum total leucocyte figure reached level of 128,000 cells per c.cm., of which 84 per cent. (ro6,240) were small, so-called 'mature to lymphocytes. On one occasion 2 per cent. lym phoblasts were found in the peripheral blood.

The literature is reviewed and the differentia diagnosis discussed.

Our thanks are due to Dr. Elizabeth Williamson recently House Physician, and to Dr. K. Ho Tallerman (London Hospital), Consulting Paedi을 atrician, for his help and advice.

Since this paper was completed Moyer åg d Fisher (1950) have published a paper on the cong dition in which they refer to a paper by Peterman et al. (1949), where a total leucocyte count .op 147,000 cells per cmm. was recorded.

\section{BIBLIOGRAPHY}

BELOFF, J. S., and GANG, K. M. (1945), Ұ. Pediat., 26, 586. BIRGE, R. F., and HILL, L. F. (1945), Amer. F. Clin. Path., 15, 508. DUNCAN, P. A. (1943), Amer. F. Dis. Child, 66, 267.

DUNCAN, P. A. (1945), New England 7. Med., 233, 177.

FINUCANE, D. L., and PHILlIPS, R. S. (1944), Amer. F. Dis. Child, 68, 301.

KILHAM, L., and STEIGMAN, A. J. (1942), Lancet, ii, 452.

LORENZ, M., HARDY, L. M., and ALT, H. L. (1946), F. Amer. Med. Ass., 13i, 882.

MacINNIS, H. F. (1946), Canad. Med. Ass. F., 55, 133.
MOYER, J. B. (1.950), Blood, 5, 666.

PEARSON, W. J., and NEWNS, G. H. (1937), Lancet, 11, 254 PETERMAN, M. G., KASTER, J. D., GECHT, E. A., and LEMBERT, G. L. (1949), Paediatrics, 3, 124.

RAYERSBACH, G., and LENERT, T. F. (1941), Amer. F. Dis Child., 6r, 237.

SITA-LUMSDEN, E. G. (1947), Brit. Med. F., 1, 849.

SMITH, C. H. (1941), Amer. Y. Dis. Child, 62, 231.

SMITH, C. H. (1944), f. Amer. Med. Ass., r25. 342.

TIDY, H. L. (1950), Postgrad. Med. F., 26, 9.

\section{RUTHIN CASTLE, NORTH WALES}

A Clinic for the diagnosis and treatment of Internal Diseases (except Mental or Infectious Diseases). The Clinic is provided with a staff of doctors, technicians and nurses.

The surroundings are beautiful. The climate is mild. There is central heating throughout. The annual rainfall is 30.5 inches, that is, less than the average for England.

The Fees are inclusive and vary according to the room occupied.

For particulars apply to THE SECRETARY, Ruthin Castle, North Wales.

Tolegrams : Castle, Ruthin.

Telephone : Ruthin 66 . 